\title{
The Learning of Arts and Cultures in the Farm Field School for the Illegal Indonesian Migrant Workers' Children: A Case Study from Community Learning Center (CLC) at Sabah, Malaysia
}

\author{
Slamet Subiyantoro ${ }^{1}$, Tjahjo Prabowo ${ }^{1}$ \\ ${ }^{1}$ Fine Arts Education Study Program, Faculty of Teacher Training and Education Faculty, \\ Sebelas Maret University, Surakarta \\ s.biyantoro@yahoo.co.id
}

\begin{abstract}
The aim of this study is to explain the status of the school and the materials of arts and cultural learning that is taught to the students with CLC (Community Learning Center) based. The location of the study was taken purposively in three locations; CLC Belinin, CLC Serat Bangsa Kimanis and CLC Ladang Cepat. This study is a qualitative naturalistic study. The technique of the data collection is done by active observation, indepth interview, and documents and archives analysis. The researchers used the triangulation method to the source of informant, places and events, and the source of the documents and achieve to check the data validity and reliability. To make accurate conclusions, the data was analyzed with interactive technique where the data is collected, reduced, verified, and presented. The data analysis is conducted couple of times continuously in a certain cycle to generate a valid conclusion. The result of this study shows that CLC is a unique learning method for children from the illegal Indonesian migrant workers because it is located in a foreign country which is in Malaysia. The location of the school is far from the city and the learning teaching process is informal, but the status of the organization of the school is formally under The Ministry of Education and Culture of The Republic of Indonesia. The materials for arts and cultural learning is focused to introduce the Indonesian cultures included (1) painting (2) coloring (3) drawing batik (4) traditional games (5) singing national songs (6) traditional dances (7) learning about Indonesia and (8) plaiting arts.
\end{abstract}

Keywords: Farm field school; CLC; arts and culture; formal; informal

\section{INTRODUCTION}

\section{Background}

Educational activities are essential for a dignified life especially to change a person or group mindset to be better. The need of education is a must that cannot be postponed anymore. Without exception for Indonesian citizen who work abroad, especially those who are far from the city and even the children of Indonesian Migrant Workers are also entitled to get an education. 
However, the implementation is not fully well done either locally, regionally or nationally, even on international scope. An example is the educational problem experienced by Indonesian children who are educated abroad in Malaysia. No less than 40.000 of the Indonesian Immigrant Workers in Malaysia including those around Kinabalu are displaced and require an educational [1].

The difference between the expectations with this reality becomes the serious problem if it is not overcome yet. This problem does not only impact to the decreasing of national competitiveness but also make worse the level of economic social life, because it is not supported by a good and proper education. Moreover, this problem is experienced by Indonesia itself that is in the subordination condition as the family, where its existence as the illegal workforce in foreign such as Malaysia.

Therefore, this research focuses on the issues of arts and cultures as a means to encourage/ build up nationalism for illegal Indonesian Migrant Workers children'. Furthermore, this research will discusses on firstly is on how the existence of CLC is used as a place to learn about values. Secondly, arts and cultures as a subject that is used to implement nationalism into group of learning in farming schools.

The aims of this study is to examine the existence of CLC as a model of education for Indonesian people who lived in Malaysia and also to find out how cultural arts as a subject is socialized to build nationalism. This research is expected theoretically beneficial in developing on social educational science and humanities educations. Practically, it is hoped to give an input for the local Educational Manager also The Ministry of Education and Culture in terms of learning arts and cultures to enhance spirit and nationalism of Indonesian who live in Sabah, Malaysia.

Education plays an important role to enhance the spirit and nationalism values as an effort to strengthen the unity of a nation. Especially, it is done in other countries in Malaysia for an example. Education also plays a strategic role through various subjects at every level of education such as Early Childhood Education, Primary School and Junior High School as well as in Senior High School. Some studies of art education related with character and value of nationalism can be seen below.

\section{Literature Review}

Studies about Indonesian Immigrant Workers in Malaysia have been conducted by several researchers from various fields of science. Astuti [2] examines about a life from social and economic perspective of Indonesian Immigrant Workers (TKI) and Female Immigrant Workers (TKW) in Malaysia and their impact on social and physiological for children's education. Sarsito, et al. [3] study about the welfare aspect of workers from Indonesian who works specifically in Kedah, Malaysia. While Subadi [4], study about migrant workers who became citizens of Malaysia. Furthermore, it was used by migrants to overcome poverty and a solution of educational cost for the children.

Benedict, et al. [5] focused on migrant workers in Sabah, East Malaysia. This research discusses on the importance of laws and policies as a foundation of equal rights towards gender, reproduction and health issues. Subiyantoro [6], researching on Indonesian children's schools in Kinabalu which is the center of formal school institutions starting from elementary school, junior high school and until senior high school. It is illustrated that children are studying at school integrated across three schooling levels from primary to senior high school using 2006 Lesson Level Curriculum and some have implemented 2013 curriculum. Alif, et al. [7] reported that 
in a real - time workshop which is focuses on children who are studying in a farming school around palm oil plantation far away from the center of the city in Sabah, Malaysia.

The Ministry of Education and Culture of Indonesia (2016) reported that basically an education that took place in Community Learning Center (CLC) is formal because the students must take national exam which is conditioned by the designated school in Malaysia. It is reported that farming school is an educational development from open Junior High School.

Although the above researches discussing about Indonesian women workers, Indonesian migrant workers, and children education but there are some aspects that have not been studied. First, there are no studies about farming schools based on Community Learning Center schools that use arts and cultures subjects. Second, research orientation that specifically discusses on spirit and nationalism aspects has not been studied.

Koo [8] researching on art educational which is used for people who lived in a remote area. This educational research is a case study conducted in United States (USA) which is viewed from culture, economic, physical situation, and different backgrounds point of views. The result of this research shows that all of the students can be participated on enjoying an art through activities that expressing them directly. Hatzigianni et.al [9] deepens the study on the basics of social art of a younger children and opening a dialogue about values of an art toward younger children in learning and making a social meaning locally and globally. While, Nurrochsyam [10] researching on educational characters that provides an opportunity through interpreting nationalism using shadow puppets which is has a peculiarity in relation to the context of nationalism and ethical attitudes. Yabu [11] studied about cultural arts of educational model using educational infiltration approach through a cross - cultural which is used to characterize student's characters. Unlike the others Giannini [13], study about schools and its organizational management in Italy. The results of the research emphasis that educational institution and areas also social context can be maximize if they can analyze the strengths and weakness of an organization which is used to develop the internal capacity through a consistent practice to proceed on a goals to be achieved. Sutiyono [14] uses puppetry arts as a medium in developing educational characters' values which is not use a formal education. The research shows that to achieve educational characters' values can be achieved through a show of puppetry arts. Based on the background of the study above the writer is exhorted to do this study entitled.

\section{RESEARCH METHODS}

This research employs descriptive qualitative naturalistic [11]. The location of this research is in three CLC (Community Learning Center) in Sabah, Malaysia. In CLC in Sabah, Malaysia there are students which is the children' of Illegal Indonesian Migrant Workers who works in palm oil plantation. The research was conducted by exploring three different CLC, and the data was collected use (1) active participants observation, (2) in - depth interviews, and (3) content analysis. Active participants observation is carried out during the course whether in the classroom or in the outside classroom. The observation also carried out around the object of observation and around neighborhood 
[15]. In - depths interviews freely focused [16] were conducted with the key informants such as teachers, parents, and the students themselves and also the local schools principal. Documents/ archives are traced through documents such as student records, report cards, and any other relevant documents. A purposive sampling technique is used to choose the informants, the locations, and documents/ archives based on the same purposes and characteristics. Triangulation source is used to check the data validity to represent the reality of a phenomenon which is through cross - checking informants source, locations, events and also the source of documents/ archives [17]. In generating an accurately conclusions, the data was analyzed using interactive techniques as follows data collection, data reduction, data presentation, and data verification. The analysis is done repeatedly on a continuous cycle until accurate conclusions are obtained [18].

\section{RESULTS AND DISCUSSIONS}

TABLE 1 PROFILE OF 3 CLC

\begin{tabular}{llll}
\hline \multirow{2}{*}{$\begin{array}{l}\text { Points/ } \\
\text { Informations }\end{array}$} & \multicolumn{2}{c}{ Comunity Learning Center (CLC) } \\
\cline { 2 - 4 } & Serat Banga Kimanis & Belinin & Ladang cepat \\
\hline Physical & Permanent, floor, 61 $\mathrm{m}$ & Wood 32 $\mathrm{m}$ & Permanent, ceramic,170 \\
Motive & Thoughtfulness & Read and write & Educational Sympathy \\
Established & 2009 & 2013 & 2012 \\
Ownership & Private Companies & Private & Private Companies \\
Range & PAUD, SD, SMP & SD & SD, SMP \\
Students & 63 & 30 & 78 \\
Study Hours & Morning and Afternoon & Morning 7-11 Evening 16- & Morning 7-13 \\
& & 18 & \\
Teachers & 2 local resident & Local & 2 \\
Teachers & SLTA & SLTP, bachelor & Bachelor, SLTA \\
education & & & \\
Language & Indonesian - Melayu & Indonesian & Indonesian - Melayu \\
Curriculum & KTSP 2016 & KTSP 2016 & KTSP 2016 \\
Process & Flexible & Flexible & Flexible \\
Graduation & National Exam & National Exam & National Exam \\
\hline
\end{tabular}

The physical conditions of two CLC are permanent, while the other CLC in Belini are still made from wood. From the two permanents building, the floor on one building is still not from ceramics (CLC Ladang Cepat), while the other is from ceramics CLC Surat Banga Simanis. The buildings are still relatively small to be arranged like a normal school building. Furthermore, the CLC layout and shape are like a normal house. Because of its unusual appearance, the CLC is informal (as an ordinary house) not like a formal school building.

The CLC learning model are based on the concerns for the children of Indonesian Migrant Workers who can only work in the fields but do not have the ability to read and write (CLC Kimanis). It is so alarming that CLC was founded. The existence of this schools also due to the sympathize (CLC Belini) of business owner to help the employees' children to get a proper education.

The births of this three CLC in different places are not at the same exact time. The first to build is CLC Kimanis which is founded on 2009, then CLC Ladang Cepat 
on 2012 and last is CLC Belini on 2013. These CLC are pioneered by the business owner who owned the palm oil plantation where their parents worked. In the social science, the condition of the presence of the schools and the existence of entrepreneurs cannot be separated from mutual interest between employees and employers. The term used in social science are often referred as patron and client. Patrons are needed for subordinates which will strengthens and support his existence. While clients also need to continues his live through the help from patrons.

In term of time during learning sessions both of them are in the morning and afternoon, and only one CLC which operates in the morning. The time of the lesson is adjusted to the situation and condition of children who helped their parents work in the palm oil plantation. Nevertheless, the spirit and the learning process carried out on stable condition even though the duration of learning process is quite short about two until three and half hours. Those time impressed was not quite enough like any other formal school which is lasted from 7a.m to 1p.m.

The education level are varies between one CLC and others, one CLC are from Kindergarten until Junior High School, also from Elementary School and Junior High School, and even only Elementary School. The teachers are varies from local residents and volunteers and handful teacher with bachelor degree. The learning conditions are often adjusting on the students' interest. The school runs flexibly with the condition of limited facilities and teachers. The learning process undergo in a modified space which facilities are limited but the learning process needs to carry on.

Language uses during learning process are tends to use Malay language and partly uses Indonesian and mixed between Malay and Indonesian. Even though the learning processes are happens in Malaysia however, the student are Indonesian then it is decided to use the children' mother tongue. Although there are people from Malaysia who uses Malay that is why Malay is used to be hoped the communication are well established in school and community.

The learning processes are using the Curriculum in The Unit Level Education 2006 which monitored through Base School from Indonesian - Malaysia School in Sabah. In applying the learning processes tends to be less rigorous but more flexible or informal. The informal characteristics are represented on its flexible management. Nevertheless, the learning system remains formal because there are national exams that are centralized from the Ministry of Education and Culture coordinated through Consulate General Kinabalu, Sabah, Malaysia. 
TABLE 2 DATA ABOUT EDUCATIONAL SUBJECT BASED CULTURAL ARTS

\begin{tabular}{|c|c|c|c|}
\hline \multirow{2}{*}{ Points } & \multicolumn{3}{|c|}{ Comunity Learning Center (CLC) } \\
\hline & Serat Banga Kimanis & Belinin & Ladang Cepat \\
\hline $\begin{array}{l}\text { Values implemented } \\
\text { to } \quad \text { enhance } \\
\text { nationalism spirit }\end{array}$ & $\begin{array}{l}\text { Introducing the country } \\
\text { symbols, traditional games, } \\
\text { traditional music, cultural } \\
\text { identity pictures }\end{array}$ & $\begin{array}{l}\begin{array}{l}\text { Sing national } \\
\text { drawing batik, }\end{array} \begin{array}{r}\text { anthem, } \\
\text { coloring }\end{array} \\
\text { national monument, making } \\
\text { woven - } \\
\text { storytelling using puppet, } \\
\text { dances, read poetry, and } \\
\text { games }\end{array}$ & $\begin{array}{l}\text { Flag ceremony, drawing } \\
\text { batik, singing traditional } \\
\text { songs, and traditional games }\end{array}$ \\
\hline $\begin{array}{l}\text { Potrait of Student' } \\
\text { Nationalism }\end{array}$ & $\begin{array}{l}\text { Vigorous to know, } \\
\text { Vigorous to find out, the } \\
\text { spirit of Indonesian, singing } \\
\text { national anthem and } \\
\text { national songs proudly, } \\
\text { enthusiasm to know } \\
\text { familiarize with the culture }\end{array}$ & $\begin{array}{l}\text { Love and great desire to } \\
\text { know about Indonesian, Habit } \\
\text { of greeting the Indonesian in } \\
\text { every morning, Shout out } \\
\text { who we are Indonesian, } \\
\text { Cultural arts every Thursday } \\
\text { in } 90 \text { minutes }\end{array}$ & $\begin{array}{l}\text { Ceremony every Monday, } \\
\text { giving an information about } \\
\text { Indonesian, teaching } \\
\text { Indonesian Map, competing } \\
\text { to point out their origin in a } \\
\text { map of Indonesian, teaching } \\
\text { traditional songs makes } \\
\text { them closer and feel as } \\
\text { Indonesian which rich in } \\
\text { culture and art }\end{array}$ \\
\hline Student origin & $\begin{array}{lrr}\text { Sulawesi } & \text { Selatan, } & \text { Nusa } \\
\text { Tenggara } & \text { Barat, } & \text { Nusa } \\
\text { Tenggara } & \text { Timur, } & \text { dan } \\
\text { Sulawesi Tenggara } & \end{array}$ & $\begin{array}{l}\text { Bugis, Jawa, Indonesia } \\
\text { Timur, Ende }\end{array}$ & Bugis, Ende \\
\hline
\end{tabular}

The methods to implemented nationalism to the children are undergoing various methods such as in Kindergarten, Elementary Schools, and Junior High Schools. Those age and education levels are relevant to instill nationalism as early as possible to the children. This sustainability is particularly important in pre - schools or Early Childhood Education and Elementary Schools [19].

Drawing is a fun world for children. Drawing or painting of puppets and national identity are used to instill nationalism values. Shadow puppets belong to a well - known Indonesian cultural treasure. While, any other identities such as nation flag, the Pancasila Eagle is a symbol that should be introduced from the beginning.

In addition to drawing that appeals to children are through coloring, this method is proffered by children in low grades (grades 1 to 3 ). The colored objects are buildings that signify the characteristic of Indonesian such as National Monument. But before the coloring began, the children are to be told about the place and buildings that will be colored in order to know the capital city is Jakarta. In addition, children also need to understand the historical relics or artifacts that exist within the monument.

According to Suharya [20] activities such as playing or making an art works is fun for children. Those activities in addition can support children's creativity. In state beyond its consciousness the child's soul will be implemented with nationalism values. In accordance, coloring or making batik also fun activities for children. For example, the simplest in batik is making kawung pattern through money printing. This is another method or using visual medium to introduce the richness of Indonesian culture [21].

The other methods are through traditional games. Most of Javanese people are well informed about the game called "baksodor" or originally go back to the door, and cat and mouse game. Both games depict the familiarity of traditional culture that will mostly encounter in Javanese villages. In those games children can be participate and 
feel the satisfaction in his life involving with cultural diversity which is appear different but can be integrated [22].

Nationalism values also socialized through sing a song of national anthem Indonesia Raya which is sing every morning before the lesson begin especially for the lower grades. Furthermore, the children are singing another national song such as Sabang sampai Merauke, Satu Nusa Satu Bangsa, Tanah Airku. The song lyrics can touch the soul and spirit of the children to strengthen the sense of Indonesian Nationalism.

Another cultural arts lesson is dance. Traditional dance from Java such as cublak - cublak suweng, mbok jamu, and another dances from Bugis such as padupa dance or from Ende such as gemu fa mire dance. Children are generally very enthusiastic to know about Indonesian culture from various regions. The art approach is more appropriate in implementing good character values for students [23]. Even to strengthen nationality spirit it is used an internet as a medium to show the country symbols, the situation during ceremony, Indonesian national anthem, and national monument. All of it can be used as a social and cultural endeavor for the interaction between subjects, in example between students and those objects such as symbols to instill meaningful values [8].

Another method is through making simple woven webbing using colorful paper. This way can be as a means to trains the skill using patterns which exist in various environments which is typical Indonesian culture. An effort to instill Indonesian soul is also done through traditional music such as angklung, poetry, and storytelling with a media of paper puppets.

The result of implementing nationalism values can be seen from the expression and attitude or behavior either explicitly or implicitly. Indeed, most of the children are born abroad and never been returned in their homeland Indonesian. But, they are aware whether they were abroad but their homeland is Indonesian. They are still in passion to know, and to find out about Indonesian. Their spirit and passions as an Indonesian citizen who live abroad can be seen from their saying "Indonesian" loudly.

Their nationalism also can be seen from when they sing the national anthem Indonesia Raya proudly. Their love and passions are great to know about Indonesian slowly became a habit when entering school as a term "greeting Indonesian". Every morning they do a ceremonial as for echoing the spirits as the Indonesian citizen. All of them are indicators that the children want to know their culture enthusiastically.

\section{CONCLUSIONS}

The result of the research shows that CLC as an educational medium for children of illegal Indonesian Migrant Worker which is unique, that lived abroad in Malaysia. The schools location is far from the city and the educational process is informal however the school status is formal under the Ministry of Education and Culture of Indonesian. The lesson materials especially cultural arts is to introduce Indonesian culture such as (1) painting, (2) coloring, (3) batik, (4) traditional games, (5) singing national anthem, (6) dance traditional dance, (7) knowing about Indonesian, and (8) 
make woven art. All of it are intended to introduce, enhances spirit and passions of Indonesian' nationalism for illegal Indonesian Migrant Workers (TKI) children in Sabah, Malaysia.

\section{REFERENCES}

[1] Kementerian Pendidikan dan Kebudayaan Indonesia. 2015. Laporan Data DinamisSiswa CLC Sekolah Indonnesia di Kinabalu. Sabah: Sekolah Indonesia Kinabalu

[2] Astuti, Yuni. 2014. "Kehidupan Sosial Ekonomi TKI dan TKW Serta Dampak Sosial Psikologis Pendidikan Anak". Jurnal Pendidikan Pancasila dan Kewarganegaraan. Th. 27, Nomor 1, Pebruari 2014

[3] Sarsito, Totok, dkk. 2012. “Analysis of Indonesian Labor Welfare, Case Study: Kedah, Malaysia". Prosiding AASIC (Asian Academic SosietyComferen).SS-05-PF (2012) 18.Subadi, Tjipto. 2016. Migrant Workers become in malaysia: Village strategies to Over come poverty and cost of Education. ISSN $2407-9189$ (2016) 36-45

[4] Subadi, Tjipto. 2016. Migrant Workers become in malaysia: Village strategies to Over come poverty and cost of Education. ISSN 2407-9189 (2016) 36-45

[5] Benedict, H, dkk. 2016. "Migrant workers in Sabah, East Malaysia: The importance of legislation and policy to uphold equity on sexual and reproductive health and rights". Best Practice \& Research Clinical Obstetrics and Gynaecology. 32 (2016) 113-123

[6] Subiyantoro, S. 2017. "Monitoring dan Evaluasi KKN Pendidikan di Sabah".Laporan Monev. Surakarta: LPPM UPKKN

[7] Alief, M., dkk. 2016. "Kuliah Kerja Nyata Tematik Intregatif di Sabah, Malaysia”. Laporan KKN. Surakarta: LPPM UPKKN

[8] Koo, Ahran. 2015. "Art and eduation for underprivileged people: Community-based art projects case study". Procedia - Social Behavioral Sciences 174 (2015) 64-68

[9] Hatzigiani, M., Miller, M. G., \&Quiňones, G. (2016).Karagiozis in Australia: Exploring principles of social justice in the arts foe young children. Internasional Journal of Education \& the Art, 17 (25) 1-20

[10] Nurrochsyam, M. W., (2014) Caracter Building: Interpretation of Nationalism in Wayang. Jantra, 9 (2) 151-159

[11] Bogdan, R dan Taylor, S. 1993. Kualitatif :Dasar-DasarPenelitian (terjemahanAfandi, A.K). Surabaya: Usaha Nasional

[12] Yabu, M. 2015. "Model pembelajaran seni budaya berbasis pendekatan infiltrasi pendidikan lintas kultur dalam upaya pembentukan karakter peserta didik". Prosiding Revolusi Mental Melalui Pendidikan, 8 Desember (2015) 216-225

[13] Giannini, Marco. 2015. "Organization and Quality in School Education”. Procedia -Social Behavioral Sciences 174 (2015) 1735-1739

[14] Sutiyono. (2014). The Art of Pupperity: a Meduim to Develop The Socialization And Cultivation of Educational Values on Nationalism. Jentra, 9 (2)161-171

[15] Spradley,J.P.1979.The Ethnographic Interview. New York: Reinhart \& Winston.

[16] Spradley, J.P. 1980. The Participation Observation. New York: Reinhart \&Winston.

[17] Nasution, 1988.PenelitianKualitatifNaturalistik. Bandung: Tarsito

[18] Miles, M.B \& Huberman A.M. 1984. Analisis Data Kualitatif. Terjemahan oleh Tjetjep Rohendi Rohidi. 1992. Jakarta : Penerbit Universitas Indonesia.

[19] Suduc, M Ana dkk. 2014. "Sustainable Development in Romania in Pre-School and Primary Education”. Social Behavioral Sciences, Vol 166 Issue 9, 1187-1192

[20] Suharya. (2016). Pendidikan seni sebagai penunjang kreatifitas. Jurnal Pendidikan dan Kerajinan Seni, 1 (1) 1-15

[21] Rosala, D. 2016. "Pembelajaran Seni budaya berbasis kearifan lokal dalam upaya membangun pendidikan karakter siswa dalam sekolah”. Ritme Jurnal Seni dan Desain Serta Pembelajarannya. 2 (1) 17-26 
[22] Yuen, Celeste Y.M. 2016. "Linking life satisfaction with school engagement of secondary students from diverse cultural backgrounds in Hong Kong".International Journal of educational Reserch. 77 (2016) 74-82

[23] Kim, Deokman. 2015. "A Study on the class of education that builds students' character through film - classes at the university of liberal arts". Procedia INTE 2014. Social and Behavioral Sciences 174 (2015) 1529 - 1533.

[24] Sutopo. 1993. Penelitian Kualitatif. Surakarta: UNS Press 